\title{
NIEZNANE ŹRÓDłA „HISTORII KOŚCIELNEJ” EWAGRIUSZA SCHOLASTYKA (HE III 30)
}

Ewagriusza Scholastyka ${ }^{1}$, autora ostatniej późnoantycznej Historii Kościel$n e j^{2}$, możemy zaliczyć do pisarzy cieszących się raczej małym zainteresowaniem $^{3}$, a niesłusznie - ponieważ jest on pisarzem niestereotypowym, którego informacje, komentarze i oceny wymykają się łatwym ocenom.

Nasz autor urodził się w latach trzydziestych VI wieku ${ }^{4}$ w Epifanii, miasteczku leżącym niedaleko od Apamei (Syria Secunda). Swoje dzieło stworzył w języku greckim w Antiochii, gdzie również spędził większość życia. Wiemy, że jako przyjaciel ortodoksyjnego patriarchy Grzegorza ${ }^{5}$ znał dokumenty patriarchatu antiocheńskiego. W jego Historii napisanej ok. 594 roku można

${ }^{1}$ Podstawowe informacje i bibliografia na jego temat por. S. Leanza, DPAC I 1311-1312. Historię Ewagriusza wśród innych wczesnochrześcijańskich Historii Kościelnych omówił m.in. G. F. Chesnut, The first Christian histories. Eusebius, Socrates, Sozomen, Theodoret and Evagrius, ThH 46, Paris 1977, 191-221.

${ }^{2}$ Są dwa wydania historii Ewagriusza: Evagrius Scholasticus, Historia Ecclesiastica, PG 86/2, 2405-2906 i Evagrius Scholasticus, The Ecclesiastical History of Evagrius with Scholia, ed. J. BidezL. Parmentier, London 1898 (repr. Amsterdam 1964); w oparciu o to ostatnie wydanie został sporządzony grecki tekst Historii w wersji elektronicznej w Thesaurus Linguae Grecae, CDROM E wydanym przez University of California w 1999 roku. W oparciu o niego też będą numerowane odwołania do tekstu.

3 Na początku lat osiemdziesiątych ukazała się bardzo dobra analiza jego dzieła dokonana przez Pauline Allen w jej pracy Evagrius Scholasticus the Church Historian, Leuven 1981. Thumaczenia francuskiego dokonał A.-J. Festugiére: Évagre. Histoire Ecclésiastique, „Byzantion” 45 (1975), 188-471. W Polsce stosunkowo niedawno IW PAX wydał thumaczenie dzieła Ewagriusza na język polski: Ewagriusz Scholastyk, Historia Kościoła, tłum. S. Kazikowski, wstęp E. Wipszycka, Warszawa 1990; dwa lata temu we Włoszech ukazało się tłumaczenie na język włoski: Evagrius Scholasticus, Historia ecclesiastica. Italiano, trad. F. Carcione, Roma 1998. Niemniej jednak ilość poważniejszych prac, a nawet artykułów poświęconych temu autorowi jest niewielka.

${ }^{4}$ Zwykle przyjmuje się któryś rok między 532 a 536 , por. Allen, dz. cyt. s. 1.

${ }^{5}$ Patriarchat Grzegorza przypada na lata 570-593, por. R. Devreesse, Le Patriarcat d'Antioche depuis la paix de l'Église jusq'à la conquête arabe, Paris 1945, 119. 
dostrzec, że powstawała ona nie w stołecznym Konstantynopolu, ale w niegdyś świetnej, a w czasie jej powstawania upadającej Antiochii. Autor był m.in. świadkiem wojny Justyniana z Persami, której momentem kulminacyjnym było zniszczenie tego bogatego miasta ${ }^{6}$, a także zarazy, która pochłonęła część jego rodziny ${ }^{7}$. Znał równiez środowiska konstantynopolitańskie ${ }^{8}$. Jego poglądy religijne klasyfikuje się współcześnie jako neochalcedonizm, czyli próbę pogodzenia poglądów Cyryla Aleksandryjskiego z doktryną opracowaną na Soborze Chalcedońskim ${ }^{9}$ - na co najwyraźniej wskazuje jego uwaga, że cyryliańskie wyrażenie „z dwóch natur” i chalcedońskie w „dwóch naturach” są wzajemnie zamienne. ${ }^{10}$. Zgodnie uważany jest za osobę o wyjątkowo - jak na swoje czasy - szerokich horyzontach i nacechowaną dużą dozą obiektywizmu ${ }^{11}$. Wadą jego Historii Kościelnej, ocenionej zresztą przez Focjusza jako dziełko napisane dobrze, jest duża trudność w posługiwaniu się dokumentami, nad którymi nie do końca panuje ${ }^{12}$. Na jego usprawiedliwienie można dodać, że wynikało to czasem z jego rzetelności - ponieważ często zbyt wiernie starał się odtwarzać treść źródeł, na których się opierał, a dokumenty cytował zawsze dosłownie ${ }^{13}$, co prowadziło to zaburzenia kompozycji. Zagadnienia te szczegółowo rozpatrywała w swojej pracy Pauline Allen ${ }^{14}$. Jedną z ciekawszych części jego dzieła - i sprawiających najwięcej trudności interpretacyjnych - jest partia poświęcona rządom wybitnego władcy wschodniorzymskiego Anastazjusza (491-518) ${ }^{15}$. Trudności, które stają przed badaczem wzmaga też fakt, że sam Ewagriusz miał najwyraźniej problemy w panowaniu nad źródłami, z których korzystał w tej części Historii. Wydarzenia są tu bowiem podzielone (odmiennie niż w innych księgach), na część poświęconą zagadnieniom religijnym i świeckim (co idzie

${ }^{6}$ Por. Evagrius, Historia Ecclesiastica (dalej HE) IV 26; o zniszczeniu Antiochii IV 25.

7 HE IV 29.

${ }^{8}$ Por. Allen, dz. cyt. s. 1-3.

${ }^{9}$ Por. Allen, dz. cyt. s. 21 i nn.; taż, Neo-Chalcedonism and the Patriarchs of the late sixth Century, „Byzantion” 50(1980) 5-17.

${ }^{10}$ Por. HE II 5; zob. też Th. Camelot, Théologies grecques et théologie Latine à Chalcédoine, .Revue des sciences philosophiques et théologiques” 35(1951) 401-412.

${ }^{11}$ Por. E. Černousov, Des Evagrios Scholastikos Kirchengeschichte als eine Quelle für die Zeit Anastasios I Dikoros, „Byzantinische Zeitschrift” 17(1927) 32-33; Allen, Evagrius, 11-15; S. Leanza, DPAC I 1311-1312.

${ }^{12}$ Por. Allen, dz. cyt. s. 15; P. Janiszewski, Historiografia późnego antyku, w: Vademecum historyka starożymej Grecji i Rzymu, red. E. Wipszycka, III, Warszawa 1999, 122.

13 Por. Černousov, dz. cyt. s. 29-30; Allen, dz. cyt. s. 143; Janiszewski, art. cyt. s. 122.

14 Trudności z panowaniem nad źródłami odbijają się także i na języku Ewagriusza, który wydaje się podlegać sporym fluktuacjom zależnie od tego, z jakiego źródła korzystał. Jako przykład

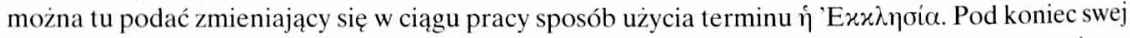

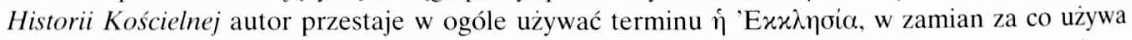
w analogicznych kontekstach słowa ó $\theta$ góvos. Nie dotyczy to jednak cytowanych dokumentów.

15 Analizę tekstu Ewagriusza pod kątem przydatności do oceny rządów Anastazjusza przeprowadził dość ogólnie Černousov, dz. cyt. s. 31-33. 
w poprzek spójności chronologicznej), i nawet tam są odnotowane bez właściwej kolejności. Tak na przykład zwolnienie z podatku chrysargyron (498) pojawia się po wojnie z Persami (502-525) a powstanie Witaliana (512-516) przed buntem z powodu Trishagion $(512)^{16}$.

Także i przesłanie, jakie autor chce skierować do Czytelnika, zastanawia. Oto Ewagriusz, pisarz bezsprzecznie bardzo ortodoksyjny ${ }^{17}$, wyraża się z dużym uznaniem o Anastazjuszu, powszechnie uważanym za zwolennika monofizytyzmu $^{18}$, nie wahając się nawet przed stwierdzeniem, że cesarz ten po śmierci poszedł do lepszego świata, czego autor odmówił na przykład Justynianowi ${ }^{19}$. Tak więc część Historii poświęcona Anastazjuszowi stawia przed badaczem wiele pytań. W artykule poniższym spróbuję odpowiedzieć na jedno z nich, a mianowicie ustalić niezidentyfikowane dotychczas źródła rozdziału III 30 charakteryzującego całokształt polityki (przede wszystkim religijnej) Anastazjusza oraz sytuację Kościołów w tymże czasie. W rozdziale tym bowiem zdaje się Ewagriusz prezentować stanowisko niezgodne z poglądami przedstawianymi w innych częściach swojego dzieła (o czym niżej).

Pauline Allen, która w swojej pracy poświęciła dużo uwagi rządom Anastazjusza, potraktowała problem źródeł tego rozdziału dość pobieżnie, stwierdzając, że jest on własną charakterystyką sytuacji kościelnej pod rządami monofi-

${ }^{16}$ Por. Allen, dz. cyt. s. 143.

17 Jego stosunek do heretyków jest widoczny w wielu miejscach. Wspominając o Ariuszu

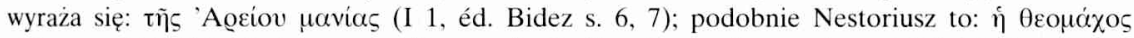

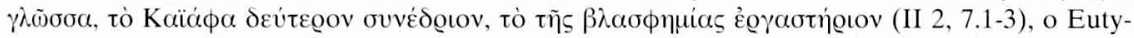

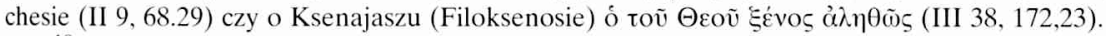

${ }^{18}$ Do dziś badacze zajmują w sprawie polityki religijnej Anastazjusza różne stanowiska, por. E. Wipszycka, Wstęp, w: Ewagriusz, Historia Kościoła, s. LIX; E. Stein, Histoire du Bas-Empire, I, ed. J.R. Palanque, Paris 1949, 78 i nn; P. Charanis, Church and State in the Later Roman Empire: The Religious Policy of Anastasius 491-518, Tessaloniki 1974, 42;. Rh. Haacke, Die kaiserliche Politik um Chalkedon r. V. Parteiischer Kompromiß: Die Henotikon-Politik unter Kaiser Anastasios I, w: Das Konzil von Chalkedon, ed. A. Grillmeier - A. Bacht, Bd. II, Würzburg 1952, s. 124 i nn.; P. T. R. Gray, The defense of Chalcedon (451-553), s. 34-44; Allen, dz. cyt. s. 142 i nn. Kroniki monofizyckie mają entuzjastyczny stosunek do Anastazjusza: np. Jan z Nikiu, The Chronicle of John, Bishop of Nikiu, 89, 36, trad. R. H. Charles, London - Oxford 1916, s. 125: „And the good deeds alone of the emperor are beyond numbering; for he was an orthodox believer and trusted in Our Lord and Saviour Jesus Christ, and prohibited the faith of the Chalcedonians because the holy Jeremiah, the servant of God had so bidden him”. Z kolei autorzy chalcedońscy dość jednoznacznie go potępiają np. Theophanes, Chronographia, ed. C. de Boor, Leipzig 1883/85, A.M. 5984; Theodoros Anagnostos: Historia Ecclesiastica, ed. G.C. Hansen, Berlin 1971, s. 125-126 i inne; Marcellinus Comes, Chronicon, ed. Th. Mommsen, MGHaa XI s. 94 pod rokiem 494; Victor Tonnennensis, Chronicon, ed. Th. Mommsen. MGHaa XI s. 192 pod rokiem 496. Z kolei, co ciekawe, pozytywnie wypowiadają się o nim wschodni autorzy piszący z perspektywy bardziej świeckiej: Joannes Lydus, De magistratibus Populi Romani, ed. R. Wuensch, Leipzig 1903, s. 98; Iohannes Malalas, Chronographia, ed. L. Dindorf, Bonn 1831, s. 393 i nn.

${ }^{19}$ Stanowi to jaskrawy kontrast z ocenami wielu innych władców, zwłaszcza Justyniana. Na ten temat patrz nizej. 
zyckiego cesarza, dokonaną przez Ewagriusza ${ }^{20}$. Kiedy jednak bliżej przyjrzymy się temu stwierdzeniu nasuwają się wątpliwości. Przecież Ewagriusz urodził się ponad 15 lat po śmierci Anastazjusza. Co więcej, znaczna część wydarzeń opisanych w tym rozdziale rozgrywała się poza Syrią - musiał więc mieć jakieś źródła (ustne czy też piśmienne), na których się oparł - na autopsji opierać się nie mógł. Nie jest jasne jak australijska badaczka pojmuje swoją tezę. Być może, ma ona na myśli nie tyle opis wydarzeń znany bezpośrednio pisarzowi, lecz raczej jego wnioski oparte o tak liczne źródła, przetworzone w trakcie pisania rozdziału, że nie jest możliwe określenie ich tożsamości. A może Ewagriusz miałby się opierać na opiniach krążących w antiocheńskich kręgach kościelnych lub w jego własnej rodzinie? ${ }^{21}$ Nie można wszakże wykluczyć, że podstawą rozdziału była kompilacja bardzo konkretnych i wcale niezbyt licznych źródeł. Spróbujmy ustalić, czy ich ślady nie dadzą się odnaleźć w tym rozdziale.

W badanym rozdziale dość wyraźnie wyodrębniają się trzy części: pierwsza $^{22}$ i trzecia ${ }^{23}$ charakteryzuje ogólnie postępowanie Anastazjusza w odniesieniu do polityki, zwłaszcza polityki religijnej, przy czym część trzecia jest kontynuacją myśli zawartych w części pierwszej. I tak, w pierwszej dowiadujemy się, że jako władca pokojowy nie chciał Anastazjusz wprowadzać żadnych nowoś$\mathrm{ci}^{24}$, w trzeciej - że ponieważ nie chciał, aby pojawiały się w Kościołach jakiekolwiek nowości, to odwoływał ze stanowisk tych duchownych, którzy tej zasady nie przestrzegali ${ }^{25}$, czego wyrazem było usunięcie dwóch kolejnych patriarchów konstantynopolitańskich: Eufemiusza i Macedoniusza, oraz patriarchy antiocheńskiego Flawiana. Właśnie ze względu na podobieństwa tematyczne, jak i strukturalne, zajmiemy się najpierw obiema tymi partiami tekstu; stanowią one bowiem pewną logiczną całość. Natomiast części drugiej ${ }^{26}$, omawiającej relacje pomiędzy ówczesnymi Kościołami, przyjrzymy się później.

Część pierwsza zaczyna się od stwierdzenia, że Anastazjusz był władcą

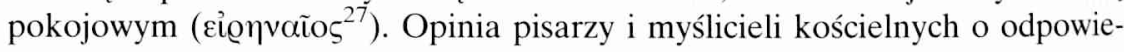

${ }^{20}$ Por. Allen, dz. cyt. s. 143: ,his own statement of the ecclesiastical situation under the monophysite emperor".

${ }^{21}$ O niektórych wiadomościach Ewagriusz zaznacza, że pochodzą z rodzinnych relacji, por. HE III 34, s. 133, 17.

${ }^{22}$ Por. HE III 30, s. 125, 32-126, 4.

23 Por. HE III 30, s. 126, 30-127, 4.

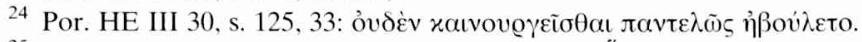

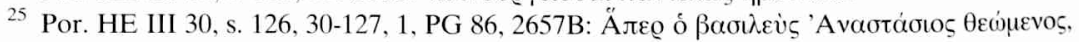
тоنे

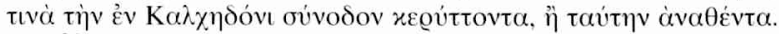

${ }^{26}$ HE III 30, s. 126, 4-126, 30 .

${ }^{27}$ HE III 30, s. 125,3 . 
dzialności władcy za pokój, sięgała czasów Konstantyna Wielkiego. Już od jego rządów zapanowało przekonanie, że dobry władca powinien się troszczyć o pokój nie tylko w państwie, ale także wewnątrz Kościoła ${ }^{28}$. Natomiast zależnie od zmieniającej się sytuacji kwestię tę widziano jako bardziej lub mniej istotną. Tak więc np. w listach od i do Leona Wielkiego z czasów Soboru Chalcedońskiego temat pokoju jest poruszany stosunkowo rzadko. Nawoływanie do pokoju między Kościołami dotyczyło tu przede wszystkim zagadnień wokół 28 kanonu soboru, zmieniającego honorową kolejność patriarchatów (ustanawiając na drugim miejscu po Rzymie patriarchat konstantynopolitański, czego Leon nie uznał) ${ }^{29}$. Sprawy konfliktowe na soborze, tj. problem Eutychesa i Dioskura, były traktowane bardziej jako problem poszczególnych niesubordynowanych jednostek, niż jako poważne zagadnienie dotyczące jedności Kościoła ${ }^{30}$. Bardzo szybko się jednak okazało, że sobór, który miał przynieść ład w Kościele, stał się zarzewiem najpoważniejszego bodajże aż do Schizmy Wschodniej konfliktu, i cesarz Marcjan już niedługo po zamknięciu jego obrad czuł się zmuszony zakazać księżom dyskusji na jego temat ${ }^{31}$.

Wkrótce też doszło do wzajemnych anatem pomiędzy poszczególnymi patriarchatami. Konflikty między Kościołami lokalnymi zaczęły narastać, zwłaszcza w VI wieku, kiedy chaos na skutek sporu monofizyckiego wewnątrz Wschodniego Cesarstwa znacznie się powiększył ${ }^{32}$; stan ten za rządów Anastazjusza opisuje także Ewagriusz, m.in. w części drugiej badanego rozdziału. Co najmniej już od Henotikonu Zenona możemy zaobserwować coraz bardziej świadome, choć w niewielkim stopniu skuteczne, wysiłki zarówno władców, jak i biskupów (przede wszystkim chalcedońskich), mające na początku za cel pojednanie monofizytów z chalcedończykami, a później - jak to możemy zaobserwować zwłaszcza od czasu rządów Justyna II - przynajmniej pogodze-

${ }^{28}$ Por. S. Bralewski, Imperatorzy późnego Cesarstwa Rzymskiego wobec zgromadzeń biskupów, Łódź 1997, s. 21: „Natomiast skłócenie wyznawców Chrystusa, samo w sobie będące obrazą Boga, a dodatkowo bierność imperatora wobec rozdzierających Kościół konfliktów, mogły ściągnąć gniew Boży na niego i rządzone przez niego cesarstwo. Tak więc to Bóg, oczekiwał od cesarzy, w ich przekonaniu, podjęcia stosownych działań na rzecz przywrócenia pokoju i jedności Kościoła”.

29 Por. Epistula Leonis ad Anatolium, ACO II 1, 2, s. 56; Epistula Leonis ad Marcianum, ACO II 1,2 , s. 58.

${ }^{30}$ Chociaż oczywiście Leon miał świadomość zagrożenia pokoju w Kościele na skutek ich działalności, por Epistula Leonis ad Flavianum, ACO II 1, 2, s. 46.

${ }^{31}$ Por. Codex Iustinanus 1.1.4; zob. też J. Daniélou - I. Marrou:, Historia Kościoła t. I, thum. M. Tarnowska, Warszawa 1984, s. 264-267; S. Bralewski, Sobór w Chalcedonie w polityce wewnętrznej cesarza Marcjana, „Acta Universitatis Lodziensis. Folia Historica” 44(1992) 53-74.

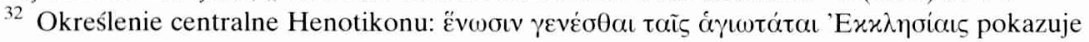
wyraźnie, że z poczuciem ładu i pokoju w Kościele za czasów Zenona już był poważny problem (HE III 14, s. 112, 4). Obrazem sytuacji za czasów Anastazjusza będzie opis konfliktów między Kościołami znajdujący się w części drugiej. 
nie coraz bardziej wewnętrznie rozbitych monofizytów ${ }^{33}$. Jednym z gorliwych zwolenników takiej irenistycznej polityki był patriarcha antiocheński Grzegorz $^{34}$, którego Ewagriusz był współpracownikiem.

Polityka ta była utrzymana w duchu neochalcedonizmu - doktryny obowiązującej w Cesarstwie od czasów Justyniana, za której zwolenników możemy uznać zarówno wspomnianego patriarchę, jak i Ewagriusza. Ważnym bowiem aspektem pastoralnym neochalcedonizmu była próba znalezienia teoretycznej płaszczyzny zawarcia pokoju pomiędzy zwaśnionymi stronnictwami ${ }^{35}$. Doskonałym tego przykładem może być fragment ze znanego traktatu Justyniana niewątpliwie najbardziej znanego - choć z pewnością nie najwybitniejszego

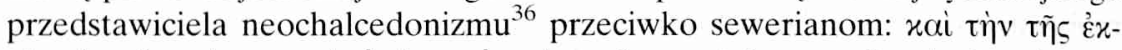

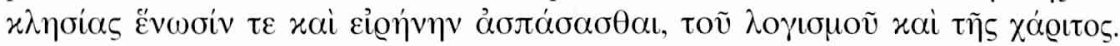

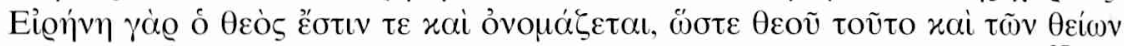

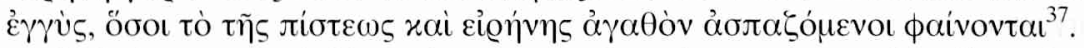

Pokoju w czasach Ewagriusza potrzebowało cesarstwo nie tylko w kwestiach religijnych, ale i politycznych. Długie wojny z Persją ${ }^{38}$ wyczerpały jego potencjał zarówno gospodarczy, jak i militarny. Zwłaszcza na zniszczonym Wschodzie pokój musiał być czymś niezmiernie pożądanym. Nie przypadkiem zapewne mniej więcej w tych latach, w których Ewagriusz pisał swoje dzieło, cesarze zaczęli używać tytułu bardzo podobnego do określenia użytego przez

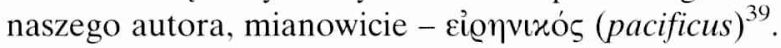

Postać Anastazjusza jako władcy pokojowego posłużyła w Historii Ewagriusza do zbudowania antytezy przeciwstawiającej cesarza dobrego tj. właśnie Anastazjusza, cesarzowi złemu - Justynianowi. Autor miał zapewne ogólny plan budowy rozdziałów końcowych i początkowych ksiąg III, IV i V; przeja-

${ }^{33}$ R. Devreesse (dz. cyt. s. 89-94) ukazuje chaos jaki panował w sferze religijnej w Antiochii niedługo przed napisaniem przez Ewagriusza Historii Kościelnej.

${ }^{34}$ Por. Devreesse, dz. cyt. s. 119.

35 Por. M. Richard, Le Néochalcédonisme, „Mélanges de Science Religieuse”, 3(1946) 156161; Ch. Moeller, Le chalcédonisme et le néo-chalcedonisme en Orient de 451 à la fin du VI siécle. Das Konzil von Chalkedon, Bd. I, Würzburg 1951, 637-720; S. Helmer, Der Neuchalkedonismus, Bonn 1962; P.T.R. Gray, The Defence of Chalcedonin the East, Leiden 1979, 104-172; J. DaniélouI. Marrou, Historia Kościota, t. I, 268-274.

${ }^{36}$ Na temat wpływu teologów neochalcedońskich na Justyniana por. M. McDonald, Leontius Jerusalem's against the Monophysites as a possible source for Justinian letter to Aleksandrian Monks, „Byzantion” 67(1997) 375-382 (bibliografia).

${ }^{37}$ Contra Monophysitas 1, w: Drei dogmatische Schriften Iustinians, wyd. II, red. M. Amelotti - R. Albertella - L. Migliardi, (post E. Schwartz), Milano 1973, s. 6, lub PG 86, 1104B-1105A.

38 Por. Evagrius, HE VI 7-15.

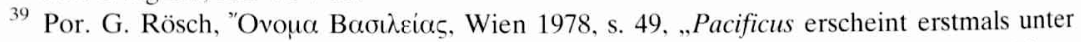
Tiberios im Urkundentitel der Kaiser; es hielt über die Titelreform des Herakleios hinaus bis zu Iustinianos II., um danach wieder zu verschwinden. In der Fremdbezeichnung war das Attribut niemals sehr häufig; am längsten hielt es sich in den Datierungen italienischer Urkunden, von wo aus es Aufnahme in den Kaisertitel Karl des Großen fand". 
wiało się to poprzez pewną symetrię w układzie treści. Księga III kończy się śmiercią Anastazjusza, a księga IV (omawiająca panowanie Justyna i Justyniana) zaczyna się stwierdzeniem, że Anastazjusz poszedł do lepszego świata. Księga IV - kończy się śmiercią Justyniana, a następna - V (omawiająca wydarzenia po jego śmierci) zaczyna stwierdzeniem, że władca ten poszedł do piekła ${ }^{40}$.

W rozdziałach opisujących rządy Anastazjusza, Ewagriusz będzie go traktował przychylnie - o ile źródła, na których się będzie opierał - często chalcedońskie, na to mu pozwolą ${ }^{41}$. Nawet przy okazji opisu buntu ludności Konstantynopola $\mathrm{z}$ roku $512 \mathrm{z}$ powodu wprowadzenia za zgodą Anastazjusza do Trishagion zwrotu, ,który za nas byłeś ukrzyżowany” (sztandarowego hasła monofizytów), autor ukazuje tego władcę nie tyle jako zmieniającego ustalony porządek heretyka, ale jako czcigodnego starca, który umie swoją rozwagą poskromić ludowe rozruchy ${ }^{42}$. Jego sposób widzenia Anastazjusza jest zdecydowanie pozytywny. Jest także oryginalny, i co ciekawe, podobniejszy raczej do opisów pisarzy zajmujących się historią świecką niż kościelną.

O Justynianie natomiast Ewagriusz wypowiada się konsekwentnie krytycznie, opisując go jako chciwca ${ }^{43}$, człowieka niezrównoważonego psychicznie ${ }^{44}$, a wreszcie - heretyka ${ }^{45}$. Wyraźnie więc autor starał się przeciwstawić dwóch cesarzy: ,pokojowego” Anastazjusza i Justyniana, który „,swoim hałasem napełnił ziemię"

Sądząc z ogólnego nastawienia jakie autor ma do Anastazjusza, przypisanie temu cesarzowi atrybutu cį̣vaĩos pochodziło zapewne od niego samego ( $\mathrm{tj}$. Ewagriusza). Pasuje ono zarówno do jego czasów jak i jego poglądów; ukształtowanych pod wpływem środowiska $\mathrm{z}$ którego pochodzil.

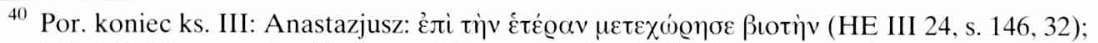

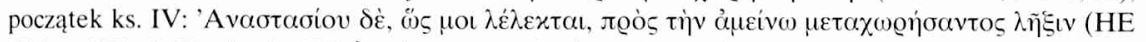

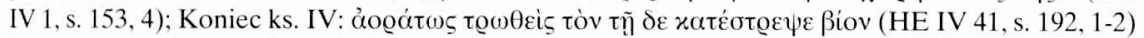

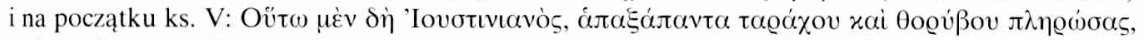

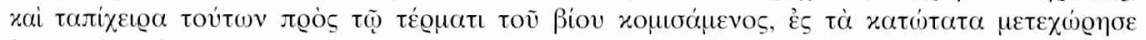

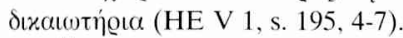

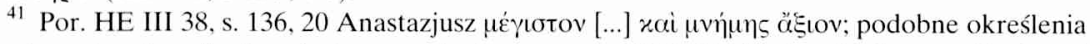
Ewagriusz stosuje, gdy Anastazjusz znosi chrysargyron (HE III 39); bardziej szczegółowo zaś Černousov, dz. cyt. s. 33 .

${ }^{42}$ Por. HE III 34; Allen, dz. cyt. s. 164; Jak wiadomo dodanie do Trishagion (odmawianego do dzisiaj w czasie Mszy w Liturgii Wschodniej) określenia „,który za nas byłeś ukrzyżowany”, sztandarowego hasła monofizytów, jest zasługą Piotra Folusznika, zob. W. Elert, Der Ausgang der altkirchen Christologie, Berlin 1957, 97-109.

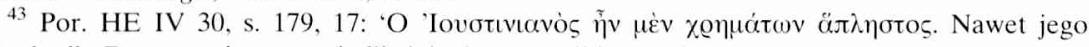
budowle dla Boga go nie usprawiedliwiają, bo wznosił je z cudzego, a nie z własnego mienia.

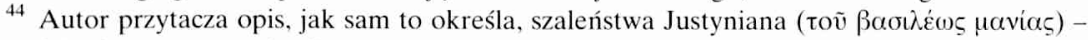
mianowicie ślepego poparcia dla stronnictwa Niebieskich (s. 149, 28; por. całe HE IV 34), które popychało go nawet do zbrodni.

${ }^{45}$ Por. HE IV 39. Warto tu dodać, że na opinii Justyniana zapewne dodatkowo szczególnie zaciążył fakt, że gdy stał się aftarodoketą, prześladował Anastazjusza - patriarchę Antiochii.

${ }^{46}$ Por. HE IV 30, s. 179, 17 i IV 39, zwł. s. 190, 1-4. 
Jeśli przyjmiemy optykę przede wszystkim polityczną, to przeciwstawienie właśnie tych dwóch władców jest w perspektywie mieszkańca Syrii rzeczą zrozumiałą. Ewagriusz jako dziecko słyszał o straszliwym zniszczeniu Antiochii za Justyniana przez Persów ${ }^{47}$, dokonanemu w dużej mierze na skutek nieudolności dowódców cesarskich. Okres rządów Justyniana, to dla niego nie tyle czasy wspaniałych podbojów, co powiększającego się chaosu i bezprawia $^{48}$. W tym kontekście czasy Anastazjusza - przez przeciwieństwo - musiały jawić się jako okres ładu i harmonii wewnątrz państwa. Potwierdzają to zresztą wykopaliska, pokazujące rozkwit Antiochii za czasów rządów Zenona i Anastazjusza $^{49}$. Taka opinia mogła więc łatwo się utrwalić w pamięci Antiocheńczyków.

Ewagriusz w omawianym rozdziale w pozytywnej charakterystyce cesarza posunął się bardzo daleko: Anastazjusz był pokojowy, ponieważ nie chciał

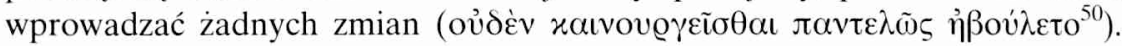
W sprawach religijnych oznacza ono w zasadzie tyle, co uznanie prawowierności władcy. Oskarżenie o wprowadzanie rzeczy nowych, była jednym z najcięższych zarzutów (zob. np. list Piotra Mongosa do Akacjusza, cytowany przez Ewagriusza $)^{51}$. Autor swoją ocenę Anastazjusza rozciąga również na zagadnienia kościelne, pisząc o pokojowej polityce tego cesarza zarówno względem tõvv

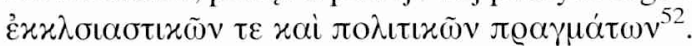

Jednakże wiele faktów, które cytuje Ewagriusz w następnych rozdziałach swej Historii wskazuje, że Anastazjusz w kwestiach religijnych nie był bynajmniej pokojowy, a co więcej, chciał właśnie do religii wprowadzać nowości. Ta sprzeczność jest jeszcze bardziej widoczna w odniesieniu do trzeciej części rozdziału III 30, rozwijającej myśl zawartą w pierwszej. Tu bowiem autor wymienia jako dowód tzw. pokojowej działalności cesarza Anastazjusza odwołanie trzech biskupów: Eufemiusza i Macedoniusza - dwóch kolejnych patriarchów Konstantynopola, oraz Flawiana - patriarchy Antiochii; ci sami trzej biskupi, którzy zostają tu przez Ewagriusza ukazani w świetle niekorzystnym, później występują jako postacie pozytywne, a nawet bohaterskie, zaś postępki cesarza wobec nich musi czytelnik ocenić krytycznie ${ }^{53}$.

${ }^{47}$ Por. HE IV 26, Allen, dz. cyt. s. 1.

${ }^{48}$ Por. zwłaszcza HE IV 30.

${ }^{49}$ Por. G. Downey, A History of Antioch in Syria, from Seleucus to the Arab conquest, Princeton 1961, s. 503.

${ }^{50}$ Por. HE III 30, s. 125, 32-33.

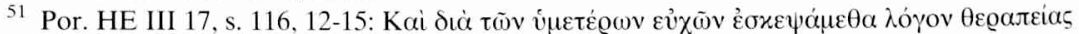

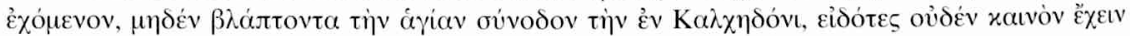

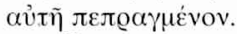

52 HE III 30, s. 126, 3-4.

${ }^{53}$ Ewagriusz wspomina także w pewnym miejscu o tym, że władca był humanitarny wobec buntujących się biskupów z rodzinnego miasta autora, tj. Epifanii (HE III 34), ale jest to świadectwo osobistej szlachetności Anastazjusza, a nie prawowierności. 
Pierwszy z nich, Eufemiusz, patriarcha Konstantynopola intronizowany jeszcze w czasach Zenona, miał, jak wiemy, poglądy zdecydowanie prochalcedońskie i nie podpisał Henotikonu ${ }^{54}$. O mężnej postawie tego biskupa wiedział i Ewagriusz. Notuje on, że Eufemiusz przed koronacją Anastazjusza zażądał od niego podpisania oświadczenia, w którym tenże zobowiązał się, że nie będzie wprowadzał nic nowego do Kościoła ${ }^{55}$, na co - jak wynika z kontekstu przyszły cesarz miał najwyraźniej chęć. Żądanie tego typu deklaracji było zjawiskiem nowym w Kościele i Cesarstwie, najwyraźniej wymuszonym przez niepokojące patriarchę okoliczności, nie zaś częścią pewnego obyczaju. Anastazjusz, o ile wiemy, był pierwszym kandydatem na władcę, od którego zażądano takiej „deklaracji lojalności”. ${ }^{56}$ Ewagriusz musiał sobie z tego zdawać sprawę.

Kolejnego patriarchę - Macedoniusza, który był mniej radykalny od poprzednika i - jak to wiemy z innych źródeł - podpisał Henotikon ${ }^{57}$, Anastazjusz usunął według Ewagriusza przy pomocy niegodnych podstępów z tego powodu, że ten nie chciał mu wydać wcześniej wspomnianej deklaracji. Postawę Macedoniusza uważa Ewagriusz za zupełnie właściwą pisząc, że postąpił tak, bo nie chciał zdradzić wiary ${ }^{58}$.

Flawian - najbardziej ugodowy z trzech biskupów ${ }^{59}$, zostaje usunięty przez Anastazjusza, zgodnie z opiniami naocznych świadków cytowanych przez Ewagriusza, na skutek prowokacji Filoksenosa (Ksenajasza) ${ }^{60}$ - jednego z głównych przywódców monofizytyzmu w Syrii, ocenianego oczywiście przez autora Historii jednoznacznie negatywnie.

A zatem Ewagriusz jednocześnie chwalił Anastazjusza za pokojową politykę i podawał fakty wskazujące na coś wręcz przeciwnego. Skoro więc wypowiadał tak sprzeczne opinie na temat tych samych osób i faktów, to wyklucza to w jego przypadku opieranie się na rozpowszechnionej opinii, bo nie byłaby ona tak wewnętrznie niespójna, wyklucza też samodzielne opracowanie oparte na wielu źródłach; autor dokonałby bowiem ujednolicenia. Źródłem więc tej niespójności tekstu musi być fakt, że nie prezentował tutaj swoich własnych refleksji, lecz oparł się na jakichś źródłach, których wymowy nie sharmonizował.

${ }^{54}$ Por. P. Cocchini, Eufemio di Costantinopoli, I 1275.

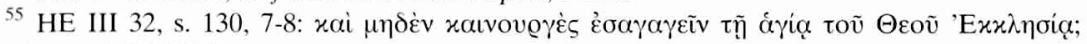
Theophanes A.M. 5983.

${ }^{56}$ Por. R. Lim, Public Disputation, Power, and Social Order in late Antiquity, Berkeley - Los Angeles - London 1995, s. 152.

${ }^{57}$ Macedoniusz podpisał Henotikon, por. Theodoros Anagnostes s. 128; Victor Tunnunensis rok 497, Zacharius Scholasticus, Vita Severi, PO 2, 113; Stein, dz. cyt. s. 166.

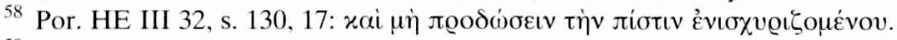

${ }^{59}$ Por. np. Devreesse s. 118 - Flawian został mianowany patriarchą właśnie dlatego, że podpisał Henotikon; Theodoros Anagnostes IV 454, s. 128.

${ }^{60}$ Por. HE III 32. 
Jak można sądzić z listy wymienionych biskupów, tam gdzie autor chwalił Anastazjusza, opierał się na źródle monofizyckim, i to wywodzącym się z tradycji seweriańskiej - wrogiej Henotikonowi, i nie tylko Eufemiuszowi, ale nawet Flawianowi, który dla bardziej umiarkowanych monofizytów (np. dla Jozuego Stylity) był wzorem wszelkich cnót ${ }^{61}$. Nie jest łatwo odpowiedzieć na pytanie na jakim źródle mógł się autor oprzeć. Nie znamy żadnego tekstu, którego badane partie rozdziału 30 byłaby wierną kopią, choć istnieje jeden dość prawdopodobny ślad. Otóż w pewnym miejscu Ewagriusz powołuje się na jakąś biografię słynnego monofizyckiego patriarchy antiocheńskiego, Sewera. Jest nim zapewne monofizycki Żywot Sewera Zachariasza Scholastyka ${ }^{62}$, autora wielokrotnie wykorzystywanej przez Ewagriusza, a nie zachowanej monofizyckiej Historii Kościelnej. Żywot pierwotnie napisany ok. 515 roku po grec$\mathrm{ku}$, zachował się jedynie w tłumaczeniu syryjskim ${ }^{63}$. Przy pomocy właśnie tego dziełka autor zrekonstruował wypadki związane z wypędzeniem z klasztoru Sewera przez niejakiego Nefaliusza; wskazują na to także podobieństwa w treści ${ }^{64}$.

Zachariasz w swoim Żywocie, komentując politykę Anastazjusza zauważył „Notre pieux empereur voulut faire disparaître les innovations que Nestoriens avaient machinée contre l'Hénotique". I jako Nestorian, z którymi cesarz musiał walczyć, wylicza - wcześniej już przez mnie wspomnianych - Macedoniusza i Flawiana. Widać tutaj więc nie tylko analogiczny schemat, ale i tych samych bohaterów; jest to zbieżność raczej nieprzypadkowa. W obu fragmentach (i w Żywocie i w HE Ewagriusza) pojawia się zarówno Anastazjusz jako cesarz walczący $z$ innowacjami, jak i wymienieni powyżej dwaj patriarchowie jako ci, którzy stali mu na przeszkodzie.

Jest więc bardzo prawdopodobne, że to właśnie Żywot Sewera posłużył Ewagriuszowi do zbudowania rozdziału III 30. Autor połączył tu własny schemat pochwał Anastazjusza jako władcy pokojowego, z opinią zaczerpniętą z Żywotu Sewera, jakoby cesarz nie chciał żadnych nowości i dlatego usunął patriarchów. W ten sposób próbował wykorzystać źródło monofizyckie do poparcia swojej koncepcji historycznej. Nie mógł oczywiście napisać, że patriarchowie zostali usunięci, bo występowali przeciwko „Henotikonowi” (co zresztą, jak wiedział, nie było prawdą), więc zamiast tego podał argumentację - co najmniej częściowo usprawiedliwiającą Anastazjusza, że biskupi ci występowali

${ }^{61}$ Por. Allen, dz. cyt. s. 146.

62 Por. Vita Severi, PO 2, 113.

63 Por. M. Kugener, Avertissement, PO 2, 4-5; oraz Janiszewski, dz. cyt. (Zachariasz z Mitylene) w: Vademecum, s. 113-115. Tam też bibliografia.

${ }^{64}$ Por. HE III 33, s. 132, 14-15; Vita Severi, PO 2, 102. Komentator thumaczenia polskiego Historii Ewagriusza nie ma wątpliwości co do tego, że autorem żywotu jest Zachariasz Scholastyk (HE tłum polskie; s. 148, przyp. 86), większe natomiast wątpliwości ma tu redaktor thumaczenia włoskiego (HE tłum włoskie s. 180, przyp. 90). 
przeciwko dotychczas panującym obyczajom. Dodajmy, że Ewagriusz mógł mieć mniejsze opory przy korzystaniu z tekstów Zachariasza niż z innych tekstów monofizyckich, ponieważ Zachariasz, już prawdopodobnie za panowania Justyna I porzucił monofizytyzm i przyjął doktrynę chalcedońską, a potem został nawet chalcedońskim biskupem. ${ }^{65}$

Po przyjęciu hipotezy o oparciu części pierwszej i trzeciej HE III 30 na Żywocie Sewera, wypada jeszcze wyjaśnić, dlaczego Ewagriusz dołączył również imię - Eufemiusza, o którym Zachariasz nie wspomina. Można to wytłumaczyć następująco: Eufemiusz był poprzednikiem Macedoniusza, także usuniętego przez Anastazjusza. Autor stara się zachować w wywodzie logikę, i wstęp uczynić przygotowaniem do później opisanych wypadków. Jednak ze względu na inne chalcedońskie źródła, na których się oparł, oraz na jego chalcedońskie przekonania, które skłaniały go do sympatyzowania ze stroną przeciwną Anastazjuszowi, ta próba się nie powiodła i dzieło utraciło swoją spójność. Znając trudności Ewagriusza z panowaniem nad źródłami nie jest to rzeczą dziwną.

\section{III}

Przejdźmy teraz do analizy części drugiej. Opisuje ona w sposób syntetyczny sytuację panującą w poszczególnych Kościołach w czasie panowania Anastazjusza - zarówno na Wschodzie, jak i na Zachodzie. Osoba, która dokonała tej charakterystyki musiała mieć doskonałą orientację w ówczesnej sytuacji. Ciekawym zbiegiem okoliczności, kiedy Capizzi w oparciu o bardzo liczne źródła usiłował odtworzyć sytuację, jaka panowała wówczas w Kościele, doszedł do podsumowań w zasadzie zbieżnych z opisem podanym przez Ewagriusza (sam się na tego autora nie powołując) ${ }^{66}$. Może to być miarą obiektywizmu i ścisłości tej partii źródła. Można jednak wątpić, czy Ewagriusz mógł być oryginalnym twórcą tego lapidarnego opisu. Gdy bowiem przyjrzymy się dalszym partiom Historii poświęconym Anastazjuszowi, zauważymy, że autor nie miał dostępu do źródeł, na podstawie których mógłby wyciągnąć tak uogólniające, a zarazem poprawne, wnioski. Do tego celu musiałby on mieć do dyspozycji materiały opisujące nie tylko to, co działo się w Antiochii i Konstantynopolu, ale w całym wschodnim Imperium, a nawet w Afryce i Italii - bo o tak szerokim obszarze traktuje część druga. Jednakże w następnych rozdziałach możemy dostrzec, że jego dane na temat rządów Anastazjusza są bardzo $\operatorname{ograniczone}^{67}$. Wystarczy spojrzeć dla porównania na rozdziały opisujące rzą-

${ }^{65}$ Por. Janiszewski, dz. cyt. (Zachariasz z Mitylene) w: Vademecum s. 114.

${ }^{66}$ Por. C. Capizzi, L'imperatore Anastasio I (491-518). Studio sulla sua vita, la sua opera e la sua personalità, (Orientalia Christiana Analecta 184), Roma 1969, s. 104-105.

${ }^{67}$ Allen (s. 143) pokazuje podstawowe błędy w chronologii Ewagriusza. 
dy Zenona, by dostrzec, że wykorzystywany przez Ewagriusza dla czasów tego izauryjskiego cesarza materiał źródłowy jest znacznie bardziej obfity, i dotyczy praktycznie całego Kościoła włącznie z Rzymem. Autor omawia sytuację w różnych patriarchatach ${ }^{68} \mathrm{i}$ to wielokrotnie, cytując również dokumenty cesarskie i biskupie ${ }^{69}$. W przypadku zaś Anastazjusza Ewagriusz nie cytuje ani jednego dokumentu cesarskiego, a tylko list mnichów palestyńskich do Alkisona $^{70}$ oraz, w skromnym zakresie, dokumenty pochodzące prawdopodobnie $z$ kancelarii Sewera ${ }^{71}$. Są to więc dokumenty mniejszej rangi i lokalne. Opisuje też wydarzenia, które dokonują się wyłącznie albo w patriarchacie Konstantynopola $^{72}$, albo Antiochii ${ }^{73}$; zupełnie przelotnie omawia się patriarchat Jerozo$\operatorname{limy}^{74}$. O Rzymie (jak i - o Aleksandrii) autor w ogóle nie wspomina, mimo ze przecież stosunki Anastazjusza z papiestwem były niezwykle ważne dla historii Kościoła, podobnie zresztą jak jego stosunki z Teodorykiem Wielkim ${ }^{75}$. Nic też nie pisze nasz autor o religijnych powodach buntu Witaliana, tak jakby o tym nie wiedział. Tak więc wydaje się, że jego perspektywa źródłowa uległa radykalnemu zawężeniu ${ }^{76}$.

A zatem, wyjąwszy badaną część, pisarz zna źródła opisujące sytuację tylko w Antiochii i Konstantynopolu. Sytuacja ta zaś przedstawia się podobnie jak w Historii Kościelnej Zachariasza, w której również w pewnym momencie znikają opisy dotyczące tego, co działo się poza tymi dwoma miastami ${ }^{77}$. Można by się zgodzić z Capizzim, że jest to zjawisko powszechniejsze w historiografii syryjskiej VI wieku: monofizytyzm zawęził perspektywę zainteresowań z obszaru Cesarstwa do samej Syrii ${ }^{78}$. Ciekawe, że - jak widać - to samo zjawisko

${ }^{68}$ Por. Aleksandria np. III 11, 12, 15 (i to o podróży patriarchy Aleksandrii do Rzymu), 16, 22; Rzym III 15, 18, 19, 20 (list papieża do cesarza Zenona i odpowiedź Zenona papieżowi); Konstantynopol III 3, 4, 5, 6, 7, 16, 21 (orientuje się nawet w relacjach akojmetów z Rzymem), 22 stosunkowo niewiele jest o Antiochii: III 10, 16, 23.

${ }^{69}$ Enkyklikos i Antyenkyklikos Basiliskosa, a także jedyny zachowany grecki tekst Henotikonu III 14 wraz z okolicznościami powstania III 13.

${ }^{70}$ Por. HE III 31 i III 32.

71 Por. HE III 44 list Sewera do Sotericha.

72 Por. HE III 32, (38), 44.

73 Por. HE III 32, 33, 34.

${ }^{74} \mathrm{~W}$ liście do Alkisona, a także przy okazji mało wiarygodnej informacji, że Anastazjusz jako heretyk został wykreślony z dyptychów (por. HE III 34, s. 134, 22-23).

${ }^{75} \mathrm{O}$ wysoce trudnych stosunkach Anastazjusza z kolejnymi papieżami zob. np. Charanis, dz. cyt. s. 48-54, a także s. 85-92 i 94-97; o relacjach z Teodorykiem Wielkim por. J. Prostko-Prostyński, Utraeque Res publicae. The Emperor Anastasius I's Gothic Policy, Poznań 1994.

${ }^{76} \mathrm{~W}$ księgach IV i V autor będzie staral się ratować, korzystając z Prokopiusza, za którym w wielu partiach swego dzieła idzie wprost niewolniczo.

77 Wyjątkiem jest lista patriarchów: Historia Ecclesiastica Zachariae Rhetoris V 6 i VII 15, thum. E. Brooks, CSCO 87, 153-154, i CSCO 88, 40-41.

${ }^{78}$ Por. Capizzi, dz. cyt. s. 107. Zarówno u Jozuego Stylity, jak i u Zachariasza Scholastyka, a także u Jana z Azji ,il teatro degli avvenimenti si restringe quasi al, solo Oriente, in modo da 
występowało również u Chalcedończyków ${ }^{79}$. Poglądy prezentowane w tej części są niewątpliwie prochalcedońskie. Pozytywnymi postaciami są ci, którzy odważnie nie chcieli zmienić ani jednej litery Soboru, a nie ci, którzy dali się oszukać treści Henotikonu, ani tym bardziej ci, którzy rzucali klątwy na Sobór ${ }^{80}$.

Tak więc część drugą również musiał autor zaczerpnąć z jakiegoś źródła, i było to zapewne jakieś syntetyczne źródło chalcedońskie ${ }^{81}$, a nie przerobione monofizyckie (zwłaszcza, że szeroka orientacja w sytuacji Kościoła powszechnego nie była, jak zauważyliśmy wcześniej, mocną stroną monofizytów). Wydaje się jednak, że niewiele więcej można powiedzieć na jego temat. Analiza części drugiej pozwala również zrozumieć niektóre z motywów, jakimi mógł się kierować Ewagriusz korzystając wcześniej ze źródła seweriańskiego - w części I i III. Autor cierpiał po prostu na brak źródeł. Tenże właśnie brak zarówno uniemożliwił mu dokładniejszą rekonstrukcję kolejności wydarzeń w czasach Anastazjusza, jak i zmusił autora do posiłkowania się źródłami heretyckimi.

$* * *$

Tak więc 30 rozdział księgi III jest fragmentem szerszej konstrukcji, znajdującej się wewnątrz Historii Kościelnej, przy pomocy której chciał Ewagriusz przeciwstawić pokojowego, dobrego Anastazjusza złemu, wojowniczemu Justynianowi. Jak już zaznaczyliśmy, jest to zrozumiałe w perspektywie mieszkań-

quasi perdere di vista non solo l'Occidente latino, ma lo stesso mondo bizantino europeo e microasiatico".

79 To zawężenie bazy źródłowej autora mogło się brać też z innej przyczyny; być może po odsunięciu Sewera dokonano poważnych czystek w archiwach antiocheńskich; trzeba pamiętać, że np. praktycznie całe znane nam teksty Sewera nie zachowały się po grecku, ale po syryjsku.

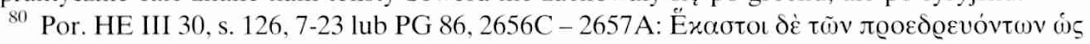

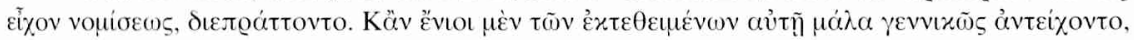

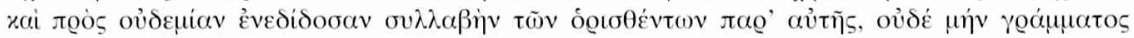

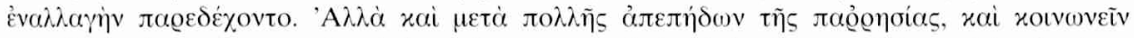

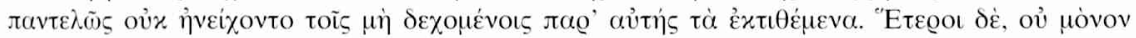

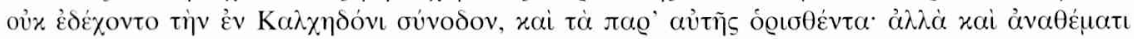

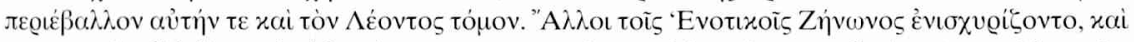

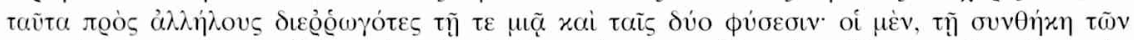

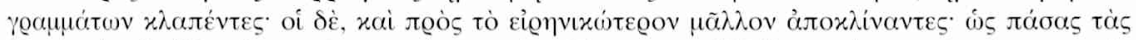

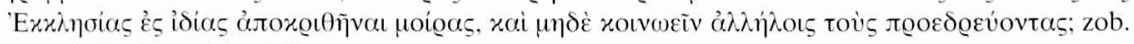
thum. S. Kazikowski s. 141.

${ }^{81}$ Być może to właśnie z tego źródła zaczerpnął Ewagriusz w rozdziale III 30 na końcu części

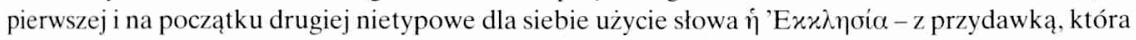
w innych przypadkach pojawia się w takim kontekście wyłącznie w cytowanych przez autora

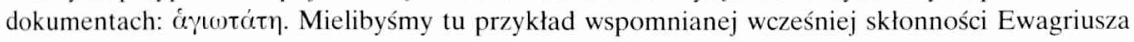
do ulegania wpływowi źródeł. 
ca Antiochii, dla którego rządy Justyniana były pasmem katastrof. W syntetycznym opisie rządów Anastazjusza wykorzystał autor pewne źródło monofizyckie, najprawdopodobniej Żywot Sewera, korzystając także z nieznanego nam, a dobrze poinformowanego źródła chalcedońskiego (część druga rozdziału). Ponieważ źródło monofizyckie było dlań wygodne, gdyż wspierało tezę o Anastazjuszu jako o władcy pokojowym, autor zachował jemu wierność, mimo że w ten sposób osłabił spójność dzieła. W rezultacie omawiany rozdział stał się sprzeczny z dalszymi partiami. Zapewne pisząc o Anastazjuszu, historyk chętnie sięgnąłby do źródeł chalcedońskich, lecz takich widocznie nie miał do dyspozycji. Posiadając mało materiałów na temat rządów Anastazjusza, musiał skorzystać ze źródeł przypadkowych, także monofizyckich ${ }^{82}$.

Jest więc ten rozdział próbą dokonania własnej charakterystyki sytuacji w Kościołach przez Ewagriusza - i tu w pewnej mierze wypada zgodzić się z przytoczoną na początku opinią P. Allen; niemniej jednak ze względu na trudności, jakie miał autor w operowaniu materiałem, daje się odnaleźć źródła, które kompilował. Tego typu niespójności w historiografii późnoantycznej nie są odosobnione. Analogiczną sytuację można zaobserwować np. u niektórych historyków Kościoła z IV-V wieku w ich stosunku do słynnego herezjarchy Apolinarego. Filostorgios, Sokrates, Sozomen i Teodoret korzystali nie tylko ze źródeł ortodoksyjnych, ale także z Historii Kościelnej Tymoteusza z Berytos będącego apolinarystą. Dlatego też w jednym przypadku (gdy korzystają ze źródeł ortodoksyjnych) przedstawiają Apolinarego jako heretyka, a innym razem (gdy korzystają z Historii Tymoteusza), wyrażają się o nim bardzo pochlebnie ${ }^{83}$.

\section{THE UNKNOWN SOURCES OF „HISTORIA ECCLESIASTICA” OF EVAGRIUS SCHOLASTICUS (HE III 30)}

(Summary)

Evagrius Scholasticus, the author of Historia Ecclesiastica, written at the end of the sixth century, is unanimously regarded by scholars as a person - in proportion to his times - of broad horizons and objectivity. He is without any doubt an unusual writer. A good example of his originality is his description of the rule emperor Anastasius. Evagrius describes him very warmly, although the emperor was regarded as a partisan of the monophysites. Yet Evagrius, without any doubt a Chal-

${ }^{82}$ Co mu się zdarzało nie tylko w tym jednym przypadku, por. Allen, dz. cyt. s. 6-11.

83 Por. Janiszewski, Historiografia późnego antyku, art. cyt. s. 97. 
cedonian writer, places Anastasius in heaven after his death; Justinian, on the other hand, is placed in hell.

Particularly interesting is chapter III 30 of Historia Ecclesiastica, which describes the politics (above all, religious) of Anastasius and the situation in the Churches at the time. In that chapter the author presents statements, which differ not only from those of other Chalcedonian writers, but also from opinions presented in other parts of his book. The above chapter is divided to three parts. After analysing part two, which describes the general situation of the Churches, it can be concluded that Evagrius used an unknown Chalcedonian source to write it. More information can be obtained from parts one and three, which describe the politics of Anastasius.

Part one begins with the statement that Anastasius was a peaceful ruler (Eloqvaios) who did not wish to make any changes in the state of the church and for that reason removed bishops who did not accept it. That statement is an element of a larger construction which we find in Historia Ecclesiastica. Evagrius uses it to build an antithesis between the good emperor Anastasius and the bad emperor Justinian. When we analyze the incidents which took place in Syria at that time, Evagrius's sympathy toward Anastasius is not surprising; as a child he must have heard about the destruction of Antioch by the Persians, caused by the incompetence of the Byzantine military leaders. The period of Justinian's rule seemed to him to be a time of disorder and lawlessness. On the contrary, the time of Anastasius must have been remembered as one of harmony.

Hence such an opinion could easily have existed in the minds of the inhabitants of Antioch. However, Evagrius was radical in his statements: Anastasius was peaceful because he did not want to make any changes. In matters of religion this more or less amounted to saying that he was orthodox. One of the most important accusations at the time was to have done something new. It is important to note that Evagrius's opinion about Anastasius is very general: he writes of his peaceful ecclesiastical politics. Nevertheless, the information which Evagrius gives the reader in subsequent chapters shows that the emperor was not so peaceful in religious matters; he in fact states that the emperor did want to establish new things in the Church.

This contradiction is very clear in the last sentences of the chapter III 30, which develop the idea of the emperor's peacefulness. As evidence for this Evagrius writes about the deposition of three bishops: Euphemios and Macedonios, two patriarchs of Constantinople, and Flavian, the patriarch of Antioch. However, those three bishops are later depicted as heroes, and the reader therefore has to judge the emperor's behavior critically. The most probable reason for this inconsistency in the text is that Evagrius used monophysite sources in writing this chapter. A structural analysis has made it possible to establish that he probably used the Vie de Severe, written by Zachariah Scholasticus, the author Historia Ecclesiastica. He probably combined his own scheme, in which Anastasius is a good Emperor, with the opinion from the Vie that the Emperor did not want any innovations and therefore deposed those patriarchs, but he was unable to harmonise them with the other sources, mainly Chalcedonian. 